\title{
The Effects of Intermodality on Transport Routes Choice from West African Ports to Landlocked Countries
}

\author{
Bomboma Kalgora1*, Hamadou Tahirou Abdoulkarim¹, Bodjrenou Kossivi2 \\ ${ }^{1}$ School of Economics and Management, Shanghai Maritime University, Shanghai, China \\ ${ }^{2}$ Glorious Sun School of Business and Management, Donghua University, Shanghai, China \\ Email: ^research.kb@outlook.com,kalishufe@hotmail.com,kossbodj@gmail.com
}

How to cite this paper: Kalgora, B., Abdoulkarim, H.T. and Kossivi, B. (2019) The Effects of Intermodality on Transport Routes Choice from West African Ports to Landlocked Countries. Open Journal of Social Sciences, 7, 1-25.

https://doi.org/10.4236/jss.2019.75001

Received: April 5, 2019

Accepted: May 3, 2019

Published: May 6, 2019

Copyright ( $\odot 2019$ by author(s) and Scientific Research Publishing Inc. This work is licensed under the Creative Commons Attribution International License (CC BY 4.0).

http://creativecommons.org/licenses/by/4.0/

\begin{abstract}
The paper studied 5 transport corridors in West Africa, from the ports of Abidjan, Cotonou, Lagos, Lomé, and Tema, to the landlocked countries (LLCs) of Burkina Faso, Mali, and Niger. The study found 15 transport routes available from these ports to the LLCs. It used two modes of transport with their respective transport costs as variables influencing shippers in their choice of corridor route. In regards to the modes of transport, the study chose the unimodal road transport and the intermodal transport as the combination of the rail and road transport, with a projection of the cargo volume demand in 2023 from the LLCs. In addition, a survey conducted on the Togolese corridor with the aim to find from users' perspective the adequate intermodal terminal location, identified the city of Mango as an ideal host. As for the transport cost analysis attached to each of the modes of transport, the results of this study revealed that in the case of the unimodal road transport, shippers from Burkina Faso would rather choose Tema port in Ghana as optimal route, while shippers from Mali would rather choose Abidjan port in Ivory Coast, and shippers from Niger would choose Cotonou in Benin as the optimal route. Consequently, the study also found that the added parameter of the intermodal terminal of Mango on the Togolese corridor would change the routing habit of the LLCs shippers. In fact, with this parameter in line, the Togolese corridor would be optimal in terms of transport cost minimization for the Niger and Burkina Faso shippers. Based on these findings the study highlights the benefits of the intermodality which it presents to the policymakers.
\end{abstract}

\section{Keywords}

Route, Transport, Corridors, Costs, Logistics, Intermodality, Terminal, Survey 


\section{Introduction}

In recent years, a number of reports have noted that inefficient transport supply chain of cargo and high logistics costs in Central and West Africa have negative effects on trade. These are hindering growth and poverty reduction in these regions more so than in most other parts of the developing world (Arvis J.-F., et al., 2010) [1]. The transport corridors of coastal countries endowed with port facilities play a key role in the development of Landlocked Countries (LLCs). These transport corridors are critical economic links between community groups of same or other geographical regions. When a landlocked country intends to undertake international trade activity by using ports, geographical restrictions force the country to rely on a port located within the territory of a coastal country. Therefore, the country faces transport costs and risks occurring within the neighboring transit country. These geographical restrictions, costs, and risks are determinant factors in the choice of the transport route by shippers for convenience sake to ship cargo.

Over the past few decades, transport corridors have received particularly close attention, while contributing to growth and regional integration efforts in Africa. Of recent, several reports noted that transport corridors play key roles in regional integration in Africa. African Union programs such as NEPAD and the programs developed by the Regional Economic Communities (RECs) all place priority on enhancing interconnectivity and facilitating trade. They do this by focusing on transport corridors as microcosms of integration and spatial development on the continent. Thus, inefficient and over expensive logistics and transport corridors have negative effects on trade and are hindering growth and development. These negative factors hinder landlocked countries and promote isolation, driving up the prices of imports, and reducing the competitiveness of exports and businesses in West and Central African countries (Nathan Associates, 2013) [2]. Depending on the circumstances, transport corridors are by nature either competitive or supplementary to each other. In the case of the West African corridors, there is significant competition between the corridors as they do serve the same countries. Based on the report issued by ATWA (2015) [3], these transport corridors are categorized into divisions, such as the transit corridors and the intra-regional corridors. The first division connects a seaport or gateway to LLCs, while the second division crosses several countries on the latitude, from west to east (the Abidjan Lagos Corridor for example). A transit corridor normally serves one coastal country and then competes with other regional corridors for transit traffic to the landlocked countries. They serve as routes for regional trade.

The centre of the present research is found with the first division of corridors, namely the transit corridors which are basically used to transport cargo designated for other countries and are usually bounded by a border intersection at one end and an international gateway at the other. Covered by this research, the network of the five selected physical transport corridors in West Africa is con- 
ceptualized as 15 virtual overlapping transit corridors connecting five major ports (Abidjan, Cotonou, Lagos, Lomé, and Tema) to the capitals commercial cities of three LLCs (Mali, Burkina Faso, and Niger). The research carries out a transport cost analysis aiming at identifying the most competitive transport routes to and from each of the LLCs in term of transport costs. For further investigations on the transport cost advantages of the intermodal transport, the research takes into account the results of a survey suggesting the localization of an intermodal terminal on the Togolese corridor, and then calculates optimized transport cost inferred by the introduction of the intermodal terminal for the forecasted year of 2023 .

The remainder of this paper is organized in the following way. Section 2 discusses the review of the literature. Section 3 presents the data and methodology used to attain the results in Section 4, where transport corridors costs analyses are conducted. The paper concludes in Section 5 with some recommendations toward policymakers.

\section{Literature Review}

Grace W.Y.W. et al. (2016) [4] argue that changing logistics strategies and the evolving role of ports in supply chains to improve hinterland accessibility have received increasing attention in the transport literature. A research conducted by Andrius J. \& Aidas V.V. (2007) [5] revealed that for many sea gateways, the weakest link in their transport chain is their "back door", where congested roads or inadequate or nonexistent rail connections cause delays and raise transport costs. In fact, compared to the sea transport costs, the inland transport costs and other port charges often account for a larger percentage of the total costs (Lättiläl L., Henttu V., \& Hilmola O.P., 2013) [6]. Likewise, Limão N., \& Venables A.J. (2001) [7] argue that successful and efficient ports are often those that are effectively connected to their economic hinterlands by adequate and effective transport corridors. The present review of literature points out to the increasing importance of the connectivity at both a quality and quantity level between the port and its own hinterland in order to be competitive in this modern era of transport supply chain.

\subsection{Transit Corridor Performance}

The basic indicators of performance for the transit corridors are the cost and time. How much and long it is required to transport cargo from a point of origin to its final destination. Additionally to these two earlier mentioned indicators, three other indicators of which the quality of services, the infrastructure and the traffic flow of cargo have been assessed (Arnold et al., 2005) [8]. The authors assert that corridor quality is measured in terms of reliability (that is the diversity of services offered), transit time and cost ensured by shipment. In its researches, Degbe S.A. (2017) [9] asserts that the shipment of goods perspective also relies on cost and time but with a focus on the supply chain management. Its studies 
further suggested that performance can be enhanced by reducing the time and cost at specific nodes within the corridor. The quality of services is the utmost critical indicators for a transport corridor performance and hence for the effectiveness of the corridor nodes. The principal inputs into such indicators are usually time and cost which helps in recognizing the components of a transport corridor that would offer the greatest savings if they are improved.

\subsection{Shippers Route Based Choice}

With the rapidly emerging transport networks, the choice of a chain, rather than a port, becomes more critical for shipping companies, logistics service providers and shippers (Notteboom T.E., \& De Langen P.W., 2016) [10]. Scholars have been advocating investigating port choice in a global setting considering the total transport chain instead of just one of its components. Throughout gathered literature, the apparently two main decision variables influencing shippers in the choice of port to call to, are the costs and the efficiency in transport supply chain servicing. The land-leg is often more costly than ocean transport and becomes a differentiating factor in port selection. Still, Tom V. \& Cathy M. (2016) [11] found that cost and land transport systems and service levels appeared to play a dominant role in the port selection process.

The attraction of a port to its hinterland relates to the port capacity and mainly to its hinterland transport cost. As noted by Michele A., et al. (2017) [12] ports competing for throughput and of which hosted countries share common hinterland markets are only as strong as their weakest link in the door-to-door transport chain. Tom V. \& Cathy M. (2016) [11] stated that given the significant transport cost of the unimodal transport, shippers can be expected to adapt their logistics operating model and lower their service level requirements employing transport combinations lead by barge or rail. As a cost-friendly, the combination of transport modes is greatly favorable for the medium and long distance. The transport decision concentrates on choosing between logistic pathways using different maritime gateways. Instead of a matter of transport mode choice, the transport decision is characterized as a "routing" decision, as Tom V. \& Cathy M. (2016) [11] noted. A survey among Austrian shippers and forwarders, conducted by De Langen P.W. (2007) [13] also found that they were not attached to one particular port or mode of transport and could easily switch their routing behavior, especially as the commitment to use combined transport stems from the hard cost savings (Feo-Valero M., et al., 2011) [14]. Their survey concluded that in the medium and long distance, intermodal transport alternatives can leverage economies of scale and reduce their cost. This allows overruling the classic transport economics on the basis of distance advantage.

The comparative cost analysis presented by Cazzaniga Francesetti D. (2005) [15] of routing containers through the Italian ports instead of the major load centres demonstrated the idea that port competition comes into play through the expensive inland leg. Accordingly, port competition becomes a function of the 
overall network performance. Whereas ports choice is analyzed following the rationale of supply chain managers searching for faster and more cost-effective ways to transport their goods from door-to-door. The analyses of revealed preferences by Malchow M., \& Kanafani A. (2001) [16], and Malchow M., \& Kanafani A. (2004) [17] confirmed that port selection by American shippers was submitted in the overall strength of the total transport chain, as they were rather looking for the most performing solution.

Scholars of the field, like McGinnis M.A. (1979) [18] and Cullinane K., \& Toy N. (2000) [19], have been generally concentrating their study efforts on measuring the sensitivity to the cost, speed, reliability, risk for losses and damages of the transport service. Meanwhile, Tsamboulas D.A., \&. Kapros S. (2000) [20] identified three generic buyer groups of these transport services. The first category of buyers was referred to as intensive users of intermodal transportation. This category was flexible with service levels and could decide almost exclusively in function of cost. The second group was more stringent as it combined cost and quality criteria when deciding on intermodal transport options. A smaller third group hardly used intermodal transport given particularities such as refrigerated transport.

The analysis by shippers of the choice between routing alternatives confirms the findings of the many pieces of literature indicating that cost is leading. Tom V. \& Cathy M. (2016) [11] proved that even minor transport chain cost differences of less than 1.5\%, an equivalent of approximatively 20 euros in their research, prevailed in the transport decision among shippers. Several pieces of research have succeeded in establishing a relationship between reduced logistics costs and trade growth. Few authors to mention, Hummels D., et al. (1999) [21] estimated that exporters in East Asia who were able to achieve a $1 \%$ reduction in their shipping costs could realize a $5 \%$ to $8 \%$ increase in their market shares. Almost identically, a later study of operational efficiency in the South Asia Subregional Economic Cooperation (SASEC) corridor used a gravity model based on tariff reduction to estimate that a $1 \%$ reduction in transport costs would produce a 5\% expansion in trade according to (Padeco Consultants, 2004) [22].

\subsection{Freight Routing and Cost Minimization}

Several contributions can be found on freight routing and costs minimization, many of which advocate transport intermodal as means of land-leg transport efficiency in terms of costs minimization. The minimization of land-leg transport costs is the main goal of the models presented in the literature (Rizk N., et al., 2006) [23]; (Selim H., et al., 2008) [24]; (Lee Y.H. \& Kim S.H., 2000) [25]; (Chern C.C. \& Hsieh J.S., 2007) [26]; (Jang Y.J., et al., 2002) [27]. The post haulage in the intermodal transport chain is performed by road and the cost curve of intermodal freight transport thus runs parallel to unimodal road transport. Once the total intermodal cost is calculated, it is possible to make comparisons with unimodal transport. This opens the way to a series of possible scenarios that can 
be assessed using an appropriate set of tools according to (Cathy M., et al., 2011) [28].

Barnhart C., \& Ratliff H.D. (1993) [29] considered the problem of determining the minimum cost routing for each shipment with the combination of truck and rail. The costs included transportation and inventory holding costs. Likewise, Boardman B.S., et al. (1997) [30] considered the problem of determining the transportation route and the combination of transportation modes while minimizing cost and time.

\subsection{Transport Costs Minimization and Intermodal Terminal Localization Literature Use of a Qualitative Approach: Survey}

\subsubsection{The Intermodal Transport Stakeholders}

The intermodal transport industry is characterized by multiple decision makers who need to work in collaboration in order for the transport system to run smoothly. According to Jencek P., \& Twrdy E. (2008) [31], the process of development or building an intermodal terminal should be discussed from the viewpoint of the three stakeholders such as the users of the terminal, investors/terminal operators and the community (see Table 1). According to Cathy M. (2001) [32] the aims and goals of the actors involved should determine all the relevant criteria to be taken into account when analyzing intermodal terminal location.

Meanwhile, Harper D.V., \& Evers P.T. (1993) [33] indicate that non-users of intermodal transport have a worse perception of its performance than users.

\subsubsection{Qualitative Approach Used to Localizing Intermodal Terminal}

It seems dubious to not take into account practical considerations including

Table 1. Intermodal stakeholder and interests.

\begin{tabular}{|c|c|}
\hline Stakeholders & Aim \\
\hline $\begin{array}{l}\text { Terminal users } \\
\text { (transport operators, forwarders, } \\
\text { consignors and consignees) }\end{array}$ & $\begin{array}{l}\text { Their aims and goals can be conflicting. First, they } \\
\text { want minimization of the transport cost consisting of } \\
\text { the cost of the transport service and the value of the } \\
\text { transportation time. Next, in some cases, the reliability } \\
\text { and the frequency of the services are even more } \\
\text { important than transportation time. The services } \\
\text { offered by the terminal and the connection with } \\
\text { other transport modes are two additional } \\
\text { criteria for the user; }\end{array}$ \\
\hline $\begin{array}{c}\text { Terminal owners/operators } \\
\text { (Private sector) }\end{array}$ & $\begin{array}{l}\text { They are more concerned with the terminal financial } \\
\text { viability. Terminal possibility to } \\
\text { expand and infrastructure capacity are } \\
\text { important decision factors; }\end{array}$ \\
\hline Community as a whole & $\begin{array}{l}\text { Their concern is primarily with the effects of the } \\
\text { developing/building of an intermodal } \\
\text { terminal on the environment, congestion, } \\
\text { and employment. }\end{array}$ \\
\hline
\end{tabular}

Source: Adapted from Cathy M. (2001) [28]. 
qualitative specificities in intermodal terminal localization, which are a more end-user focus. Portugal L. da S., et al. (2011) [34] used the AHP method to establish a procedure for ranking locations that are candidates for cargo terminal facilities. In their research Rickard B. \& Jonas T. (2008) [35] used an approach that aims at facilitating the planning process of regional logistics systems in general and the evaluation process of intermodal terminal locations in particular. They do this by considering both public and private interests focusing on economic and environmental aspects.

Several other researches have been conducted where multi-criteria analysis was applied to select the most appropriate location out of a number of potential sites for an intermodal terminal. Researches among which, Macharis C. \& Verbeke A. (1999) [36] examined four potential sites for new barge terminals in Belgium by means of a multi-actor, multi-criteria analysis. Their criteria represent the aims of the actors who are involved, namely the users of the terminal, the operators/investors and the community as a whole.

In their paper, Sirikijpanichkul A., et al. (2007) [37] developed an integral model for the evaluation of road-rail intermodal freight hub location decisions. The model comprised four dominant agents namely, hub owners and/or operators; transport network infrastructure providers; hub users; and communities. Their agent-based modeling approach was introduced to allow such negotiation to happen in order to achieve a global objective. It presents well an initial location selection process, testing with individual objective functions. Likewise, Sirikijpanichkul A. \& Ferreira L. (2005) [38] have discussed several attempts that have been made to develop models to evaluate the optimum location of terminals.

\section{Data and Methodology Presentation}

\subsection{LLCs Imports \& Exports Demand Data}

The data used in this study, are obtained from various West African countries Chamber of Commerce and the PMAWCA (2016) [39]. Table 2 shows the cargo demand in million tons from the 3 LLCs. The data information on the corridors distances (see Table 4) and the average transport cost (see Table 5) are respectively obtained from Google map, and the Borderless. The research will refer to the basic indicators for evaluating the corridor performance of five countries,

Table 2. Demand imports \& exports data for selected LLCs in W/A (million tons).

\begin{tabular}{ccccccccccccc}
\hline & \multicolumn{10}{c}{ Year } \\
\cline { 2 - 10 } LLC & 2006 & 2007 & 2008 & 2009 & 2010 & 2011 & 2012 & 2013 & 2014 & 2015 & 2016 \\
\hline $\begin{array}{c}\text { Burkina Faso } \\
\text { (Ouagadougou) }\end{array}$ & 1.87 & 2.26 & 2.6 & 2.28 & 3.31 & 4.76 & 5.52 & 5.99 & 5.77 & 6.33 & 7.02 \\
Mali (Bamako) & 3.9 & 4.54 & 4.82 & 3.78 & 4.76 & 5.11 & 5.89 & 5.99 & 6.06 & 6.46 & 7.16 \\
Niger (Niamey) & 1.58 & 1.78 & 2.26 & 2.79 & 3.11 & 3.46 & 3.34 & 3.6 & 3.94 & 5.21 & 5.79 \\
Total & 7.35 & 8.58 & 9.68 & 8.85 & 11.18 & 13.33 & 14.75 & 15.58 & 15.77 & 18 & 19.97 \\
\hline
\end{tabular}

Source: Burkinabe, Mali and Niger's chamber of commerce and PMAWCA (2016) [39]. 
from their respective port (seen as the point of origin) to the LLCs commercial cities they serve.

The research forecast the cargo volume flow for the next 10 years (from 2017 to 2026). To attain this forecast, the researcher proceeds by simply calculating the rate of evolution by variation period of $\mathrm{n}$ and then the overall average evolution rate which is both mathematically presented as followed:

Calculation of Rate Evolution by variation of year,

$$
t_{G}=\frac{V_{j}-V_{i}}{V_{i}} \times 100
$$

$t_{G}$ : Rate of evolution by variation period of $(n)$.

$V_{i}$ : Initial volume of year $(n)$.

$V_{j}$ : Final volume of year $(n+1)$.

Calculation of Overall Average Evolution Rate,

$$
T_{m}=\frac{t_{G 1}+t_{G 2}+\cdots+t_{G n}}{n}
$$

$T_{m}$ : Overall Average Evolution Rate.

$t_{G 1}$ : Rate of evolution by variation period from $(n)$ to $(n+1)$.

$t_{G n}$ : Rate of evolution by variation period over $(n)$ period.

$n$ : number of variation period.

From the precedents mathematical calculations, we obtain the forecasted results of the cargo demand in million tons from the 3 LLCs, presented in Table 3 which starts from the year 2017. Therefore this study is using the year 2023 as a benchmark.

\subsection{Alternatives Available Corridors Route to Shippers}

Consideration is given to the transport system between an origin and destination (OD) pair in the model. The study assumes that the traffic demand is generated from major commercial cities (capital cities) of each of the three LLCs. This, due to the fact of unpublished traffic volume from other potential important commercial city centres of the studied LLCs. The 15 alternatives available corridor routes, involve three LLCs, Burkina Faso, Mali, and Niger, and five major ports, including the ports of Abidjan, Cotonou, Lagos, Lomé, and Tema (Figure 1).

Table 3. Forecasted demand imports \& exports data for selected LLCs in W/A (millions of tons).

\begin{tabular}{ccccccc|c|ccc}
\hline & \multicolumn{10}{c}{ Year } \\
\cline { 2 - 10 } LLC & $\mathbf{2 0 1 7}$ & $\mathbf{2 0 1 8}$ & $\mathbf{2 0 1 9}$ & $\mathbf{2 0 2 0}$ & $\mathbf{2 0 2 1}$ & $\mathbf{2 0 2 2}$ & $\mathbf{2 0 2 3}$ & $\mathbf{2 0 2 4}$ & $\mathbf{2 0 2 5}$ & $\mathbf{2 0 2 6}$ \\
\hline $\begin{array}{c}\text { Burkina Faso } \\
\text { (Ouagadougou) }\end{array}$ & 7.79 & 8.64 & 9.58 & 10.62 & 11.78 & 13.07 & 14.49 & 16.07 & 17.83 & 19.77 \\
Mali (Bamako) & 7.94 & 8.81 & 9.77 & 10.83 & 12.02 & 13.33 & 14.78 & 16.39 & 18.18 & 20.16 \\
Niger (Niamey) & 6.42 & 7.12 & 7.90 & 8.76 & 9.72 & 10.78 & 11.95 & 13.26 & 14.70 & 16.31 \\
Total & 22.15 & 24.56 & 27.24 & 30.22 & 33.51 & 37.17 & 41.22 & 45.72 & 50.71 & 56.24 \\
\hline
\end{tabular}

Source: Processed by the author. 


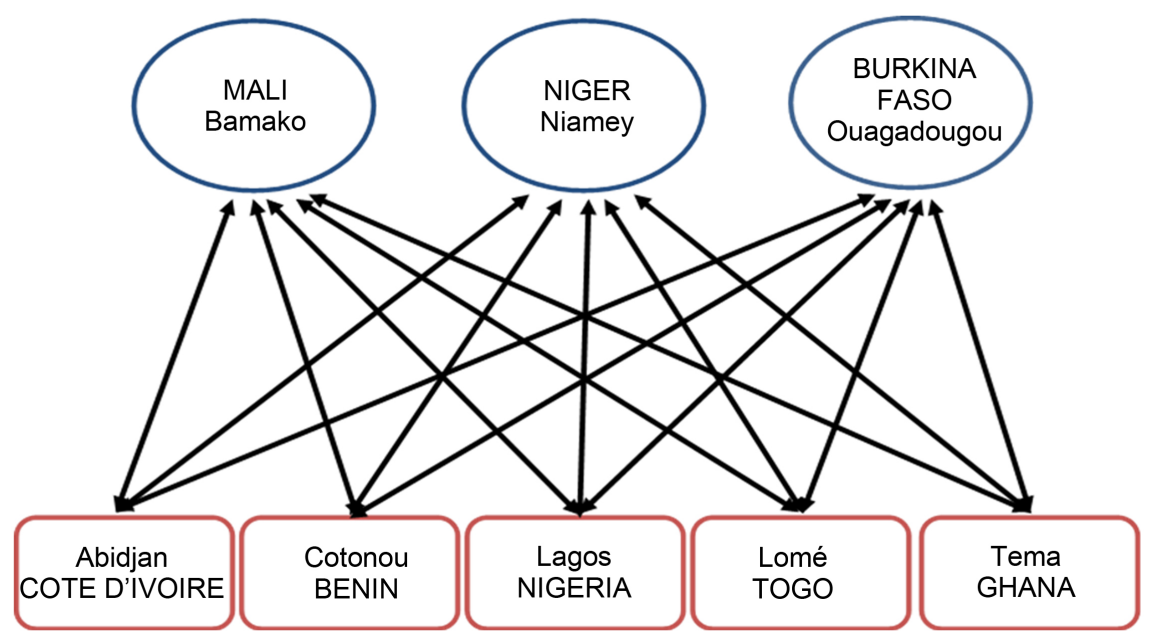

Figure 1. LLCs alternative corridor route selection (Source: processed by the author).

Instead of transport mode comparison, we are studying the selection of alternative corridors to route the containers by using different ports. A route is considered as from a point origin to a point of destination (OD) irrespective of the transport mode.

Table 4 summarizes the distance of the corridors between the five respective ports (Origin) and the major commercial cities of the LLCs (Destination).

A comparison overview of the distance from $\mathrm{O}$ to $\mathrm{D}$ is given in Figure 2. The longest corridors to and from Mali, are respectively the Cotonou-Bamako, Lagos-Bamako, Lomé-Bamako, and the Tema Bamako. Abidjan is at the shortest distance away from Bamako destination with about $1382 \mathrm{~km}$. Regarding Niger, Lagos-Niamey appears to be the shortest path, closely followed by the Cotonou-Niamey route, then the Lomé-Niamey corridor route. The Lomé-Ouagadougou corridor, is the shortest path among all other four corridors routes to and from Burkina Faso. The corridor route of Tema-Ouagadougou is the second, and followed in third position by the Lagos-Ouagadougou corridor route. Abidjan appears to be the most distant to Ouagadougou with $1232 \mathrm{~km}$. Analyzing port choices in the United States, Blonigen B., \& Wilson W. (2006) [41] concluded that distance and transport prices and individual port efficiency play a significant role in determining a port's market share. Figure 2 illustrates the length of the corridors from origin to destination.

\subsection{Average Transport Cost within Corridors}

The average transport costs in USD per ton per kilometer are represented in Table 5. This average transport price mechanism is calculated based on the fuel cost, road conditions, as well as any indirect and direct costs associated with inland transportation. Among the cheapest road transport rate, is Ghana's with $0.14 \mathrm{USD} / \mathrm{ton} / \mathrm{km}$ followed by Togo, $0.16 \mathrm{USD} / \mathrm{ton} / \mathrm{km}$. The highest transport rate is noted with Nigeria, $0.2 \mathrm{USD} / \mathrm{ton} / \mathrm{km}$. The objective is the identification of the minimal transport cost route. Hence in the following course of the corridors 
Table 4. Corridors distances from origin to destination.

\begin{tabular}{ccc}
\hline Country & Corridors & Distance $(\mathbf{k m})$ \\
\hline \multirow{3}{*}{ Cote d'Ivoire } & Abidjan-Bamako & 1382 \\
& Abidjan-Niamey & 1694 \\
& Abidjan-Ouagadougou ${ }^{*}$ & 1232 \\
Benin & Cotonou-Bamako & 1947 \\
& Cotonou-Niamey* & 1070 \\
Nigeria & Cotonou-Ouagadougou & 1200 \\
& Lagos-Bamako & 1942 \\
& Lagos-Niamey* & 1028 \\
Togo & Lagos-Ouagadougou & 1095 \\
& Lome-Bamako & 1973 \\
& Lome-Niamey & 1222 \\
Ghana & Lome-Ouagadougou & \\
& Tema-Bamako & 928 \\
TOTAL CORRIDORS LENGTH & 1967 \\
\hline
\end{tabular}

Source: Google map [40].

Table 5. Average transport cost (US\$/ton $/ \mathrm{km})$.

\begin{tabular}{ccc}
\hline Country & $\begin{array}{c}\text { Transport cost-road } \\
\text { (USD/ton/km) }\end{array}$ & $\begin{array}{c}\text { Transport cost-rail } \\
\text { (USD/ton/km) }\end{array}$ \\
\hline Cote d'Ivoire & 0.17 & 0.14 \\
Benin & 0.18 & $\mathrm{n} / \mathrm{a}$ \\
Nigeria & 0.2 & $\mathrm{n} / \mathrm{a}$ \\
Togo & 0.16 & $\mathrm{n} / \mathrm{a}$ \\
Ghana & 0.14 & $\mathrm{n} / \mathrm{a}$ \\
\hline
\end{tabular}

Source: Borderless (2016) [42].

transport cost performance analysis, where direct rail transport is available and operational, the model will make calculation utilizing the average rail transport cost instead of the average road transport cost. In the case of Abidjan to Ouagadougou, different costs are allocated to different transport modes. The transport modes considered are two namely; rail and truck.

\subsection{Intermodal Terminal Localization Using a Survey Method}

A Questionnaire was systematically administered to a chosen target population at the Port of Lome. In all, 100 questionnaires were dispatched for the survey of which 70 copies were retrieved; and only 60 copies were considered valid for the survey analysis. Information was gathered from several interviews and that data gathered was used to derive current conditions from the general perception in 


\section{Corridors Length}

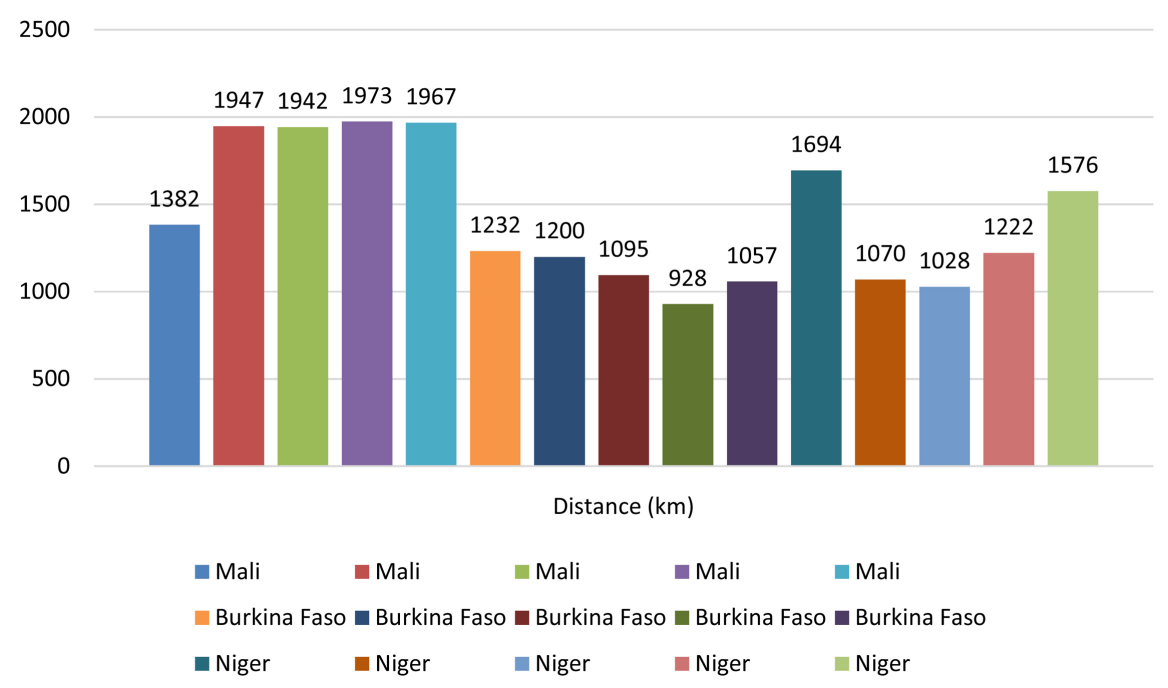

Figure 2. Corridors length. Source: processed by the author.

the transport supply chain.

This illustrates the approach used by the researcher in selecting the respondents for the case study. Random sampling was used to choose a select group of the population. This sampling method is meant to be an unbiased representation where every member stood an equal chance of being selected for sampling. It has been noted by Descombe (1998) [43] that when selecting a sample size, there are two major factors that can be explained about the population and sample size in qualitative research. Firstly, they are unlikely to be known with precision or certainty at the beginning of a research paper. Secondly, the sample size will generally be relatively small to the entire population. Hence, an adequate and comprehensive data must be obtained in order to provide a solution the outlined problems.

The questionnaire therefore mainly focused on the first stakeholders along the Lomé-Cinkassé transit corridor and extending to Ouagadougou, Niamey and Bamako. The target population subject to the survey was the freight forwarders, the truck operators, and the transit importers and exporters. The questionnaire was accompanied with an introductive letter of the researcher and its research purpose in Appendix 1. To this utilized method was added the ID Number attributed to each respondent, to actually ensure not only the anonymity of the respondent's information, but also to avoid duplicate respondents' survey. This survey technique also assures a higher response rate from surveyed participants and encourage their openness. A sample of the questionnaire can be found in Appendix 2. The results and analysis of the survey are presented in the following sections.

\subsection{Mathematical Function}

The total transportation calculation cost can simply be written mathematically as 
follow:

$$
T T C=\sum_{n=1}^{k} d_{n} D_{n} F_{n}
$$

where,

$$
\begin{aligned}
& T T C=\text { Total Transportation Cost. } \\
& d_{n}=\text { distance between two locations. } \\
& D_{n}=\text { quantity in millions of tons. } \\
& F_{n}=\text { average transportation cost in USD ton per kilometer. }
\end{aligned}
$$

\section{Empirical Results}

\subsection{Unimodal Transport Cost Analysis Forecast, for Year 2023}

The unimodal transport cost for freight transiting from each of the five major ports to the destination to each of the three LLCs commercial centres (Bamako, Niamey, and Ouagadougou) is presented in the Table 6. This freight rate comparison only considers the amount paid to the railways or the truck and does not include terminal handling costs nor loading or unloading cargo at final delivery.

By the year 2023, the volume of cargo imports and exports to and from Bamako (Mali) would increase by $128.9 \%$ from the year 2015, a yearly growth rate

\begin{tabular}{|c|c|c|c|c|c|c|}
\hline HLLC & Corridors & $\begin{array}{c}\text { Distance } \\
(\mathrm{km})\end{array}$ & $\begin{array}{l}\text { Av.Tr.Cost } \\
\text { by road } \\
\text { (USD/t/km) }\end{array}$ & $\begin{array}{l}\text { Av.Tr.Cost by } \\
\text { rail (USD/t/km) }\end{array}$ & $\begin{array}{l}\text { Demand Imp \& } \\
\text { Exp HLLC }\end{array}$ & $\begin{array}{c}\text { Unimodal-Transport } \\
\text { Cost (HLLC } \\
\text { total demand) }\end{array}$ \\
\hline \multirow{5}{*}{ Mali } & Abidjan-Bamako & 1382 & 0.17 & - & $14,780,037$ & 3472 \\
\hline & Cotonou-Bamako & 1947 & 0.18 & - & $14,780,037$ & 5180 \\
\hline & Lagos-Bamako & 1942 & 0.2 & - & $14,780,037$ & 5741 \\
\hline & Lome-Bamako & 1973 & 0.16 & - & $14,780,037$ & 4666 \\
\hline & Tema-Bamako & 1967 & 0.14 & - & $14,780,037$ & 4070 \\
\hline \multirow{5}{*}{ Niger } & Abidjan-Niamey & 1694 & 0.17 & - & $11,952,013$ & 3442 \\
\hline & Cotonou-Niamey* & 1070 & 0.18 & - & $11,952,013$ & 2302 \\
\hline & Lagos-Niamey ${ }^{*}$ & 1028 & 0.2 & - & $11,952,013$ & 2457 \\
\hline & Lome-Niamey & 1222 & 0.16 & - & $11,952,013$ & 2337 \\
\hline & Tema-Niamey & 1576 & 0.14 & - & $11,952,013$ & 2637 \\
\hline \multirow{5}{*}{ Burkina Faso } & Abidjan-Ouagadougou* & 1232 & - & 0.14 & $14,491,042$ & 2499 \\
\hline & Cotonou-Ouagadougou & 1200 & 0.18 & - & $14,491,042$ & 3130 \\
\hline & Lagos-Ouagadougou & 1095 & 0.2 & - & $14,491,042$ & 3174 \\
\hline & Lome-Ouagadougou* & 928 & 0.16 & - & $14,491,042$ & 2152 \\
\hline & Tema-Ouagadougou* & 1057 & 0.14 & - & $14,491,042$ & 2144 \\
\hline
\end{tabular}
of about $10.9 \%$. The best option route in the case where coastal countries by 2023 continue to still use a unimodal mode of transport for shipping cargo, would be first the Abidjan with USD 3.472 Billion. This is followed by Tema

Table 6. Overall unimodal forecasted transport cost by route, for year 2023 (value in Million USD).

Source: Processed by the author. 
USD 4.07 Billion and in the third position the Lomé corridor route USD 4.666 Billion (see Figure 3).

In regards to the cargo to and from Niamey (Niger) to the coastal countries, the first option route shippers might consider would likely be Cotonou USD 2.302 Billion, followed by Lomé USD 2.337 Billion and then the Lagos route USD 2.457 Billion in terms of unimodal transport costs. Abidjan and Tema are the most costly transport corridor routes among others (see Figure 4).

Though the distance between Lomé-Ouagadougou is listed as the shortest compared to other routes, Burkinabe shippers would likely in the forecasting unimodal transport cost prefer the Tema route costing USD 2.144 Billion. The Lomé-Ouagadougou route, USD 2.152 Billion would come as the second best

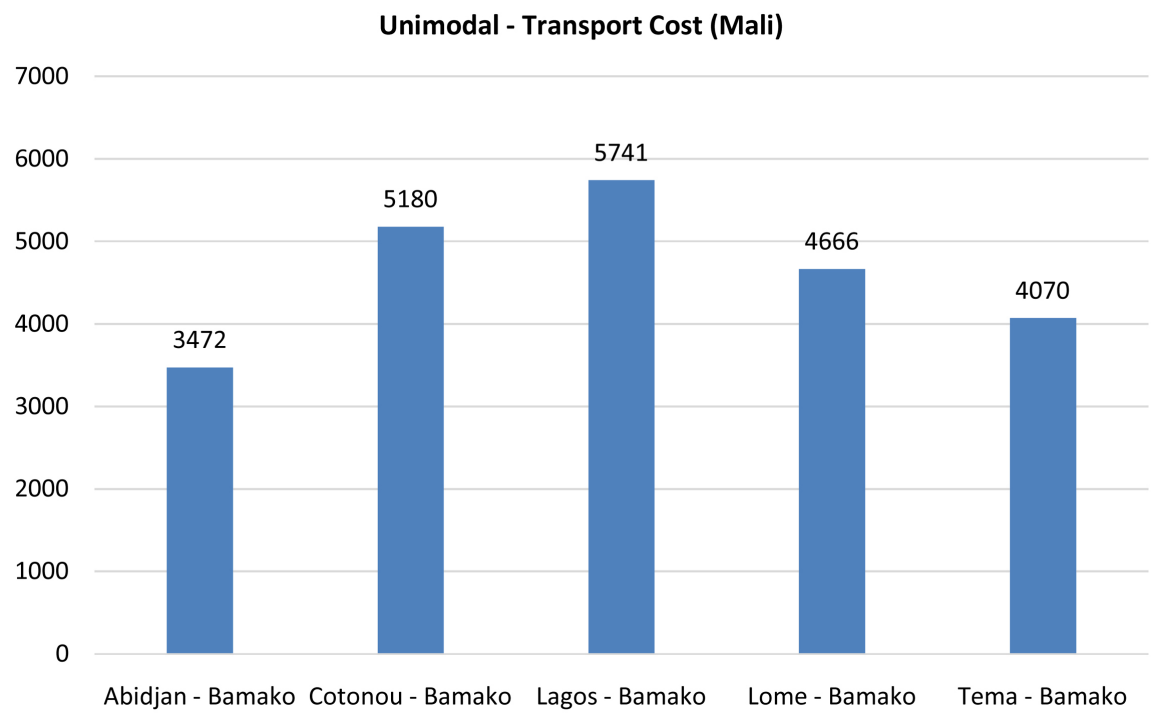

Figure 3. Unimodal transport forecasted cost route of Bamako, by year 2023 (Mali). Source: Processed by the author.

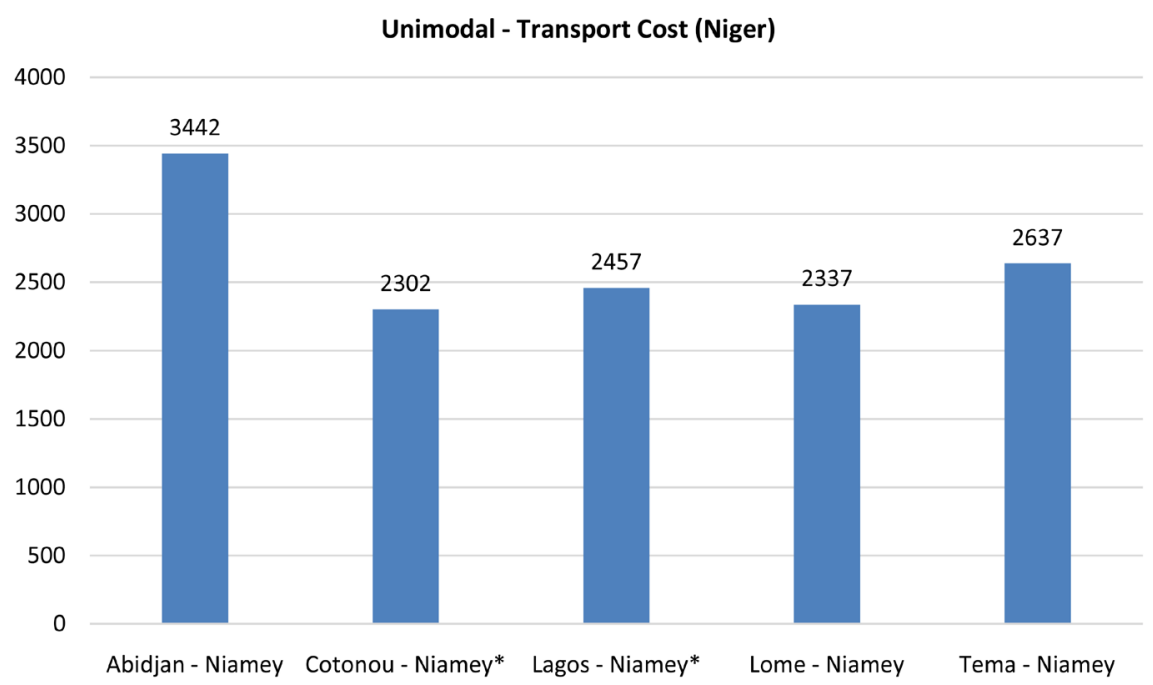

Figure 4. Unimodal transport forecasted cost route of Niamey, by year 2023 (Niger). Source: Processed by the author. 
corridor route option, followed by the Abidjan-Ouagadougou route USD 2.499 Billion. This is interesting given that cargo routed through the Abidjan-Ouagadougou corridor goes by train (see Figure 5).

\subsection{Survey Results on Intermodal Transport Localization}

In regard to the introduction of an intermodal transport system along the Lomé corridor route, $55 \%$ of the respondents opposed the idea with the majority $53 \%$ of the truckers, who argued that such transport modes would increase the rate of unemployment in the transport industry (see Table 7). On the contrary, $42 \%$ of respondents welcomed the idea of an intermodal transport system; of that $22 \%$ of the truckers and $20 \%$ of freight forwarders who stated that this would lead to transit time saving, security improvements, avoidance of the Alédjo-Mountains, transport cost reduction, and the reduction of road accidents.

Considering the choice of the intermodal terminal along the Togo corridor route, the majority of the respondents' for the adoption of an intermodal transport system, here about $36 \%$ voted in favor of the city of Mango as the best host city for an intermodal terminal (see Table 8).

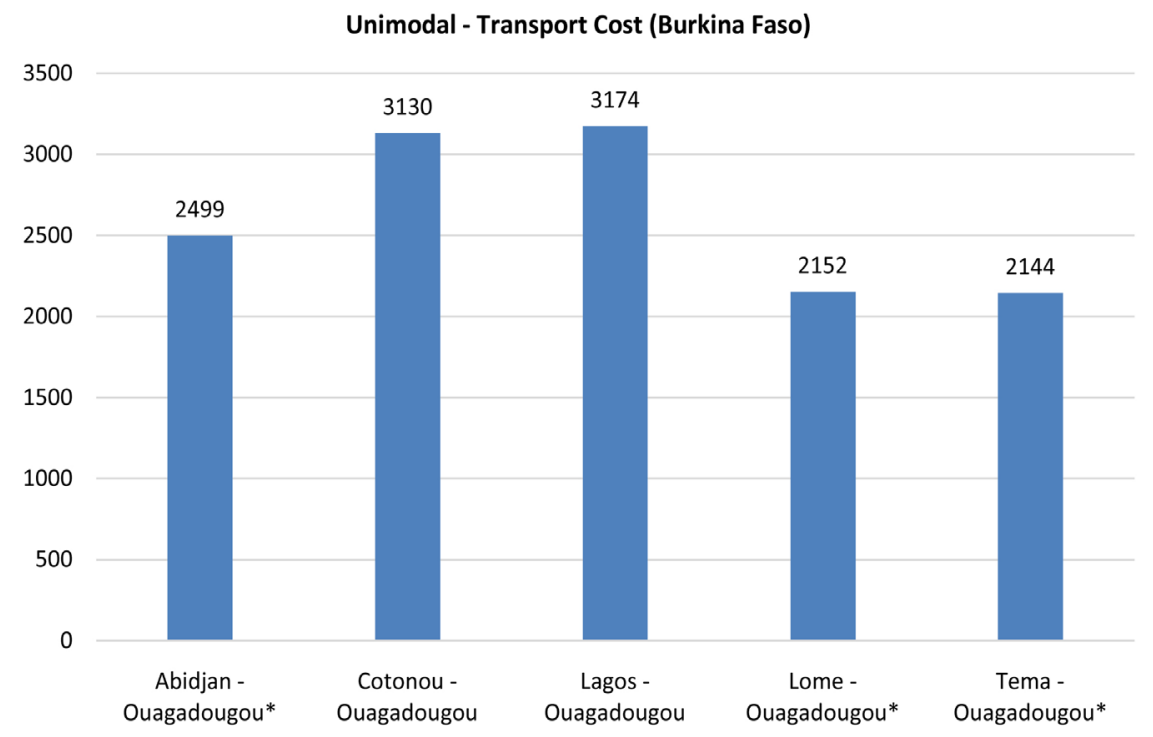

Figure 5. Unimodal transport forecasted cost route of Ouagadougou, by year 2023 (Burkina Faso). Source: Processed by the author.

Table 7. Intermodal transport system.

\begin{tabular}{ccc}
\hline Intermodal Transport Assessment & $\%$ & Number \\
\hline Yes & 42 & 25 \\
No & 55 & 33 \\
No answer & 3 & 2 \\
Total & 100 & 60 \\
\hline
\end{tabular}

Source: Processed by the Author. 
Table 8. Preselection of intermodal terminal location.

\begin{tabular}{ccc}
\hline Intermodal Terminal Preselected Locations & $\%$ & Number \\
\hline Mango (550 km from Lome) & 36 & 9 \\
Dapaong (620 km from Lome) & 28 & 7 \\
Blitta (263 km from Lome) & 28 & 7 \\
Kara (411 km from Lome) & 8 & 2 \\
Total & 100 & $\mathbf{2 5}$ \\
\hline
\end{tabular}

Source: Processed by the Author.

\subsection{Intermodal Transport Cost Analysis Forecast, for Year 2023}

In the previous section, the survey-based terminal localization gives the city of Mango, at $550 \mathrm{~km}$ north to the capital city of Lomé, as to be the best intermodal terminal location. This research, therefore, uses the survey results for calculating the intermodal transport cost of cargo flow through the Togo corridor. Calculations are thus taking into account this new parameter. The transport cost is a function of several factors such as the volume of cargo, the distance from the origin to final destination, the average transport cost by road and by rail, the demand from each LLCs, and the available mode of transport.

The choice of the best route in terms of cost minimization will depend on the total transport cost whether in unimodal or intermodal case. The total unimodal versus intermodal transport cost calculation is presented in Table 9. The section deals with analyzing transport costs by routing. This implies the comparison of the different cargo traffic flow from ports and routed to each LLCs market. The upper limit on the freight rates will be fixed by the road freight rates; i.e. the railway cannot set the freight rates higher than the road freight rates unless the customer is willing to pay more than the road freight rates. As for Rajiv D., et al. (2011) [44], they suggest that the freight rate should be set in sort to determine the optimum pricing policy and terminal location in order to guarantee a certain level of profit for the railway from the intermodal service. This means that pricing should be set in such a way that the railway can achieve profits without losing traffic to road transport.

Moreover, for the case of Togo, it is given based on our survey research that customers are not willing to pay more than the road freight rate, and therefore the truck shipping cost using the intermodal service should be less than the cost of shipping by road. Consequently, the research applies the freight rate of 0.14 USD/ton/ $/ \mathrm{km}$ as same as the one from Ivory Coast, added to the fact that these two countries share numerous similarities.

Regarding the forecasted demand, the Ivory Coast corridor offers the least inland transport cost for cargo traffic in direction and from Bamako in Mali, with a total cost of USD 3.472 Billion. This followed by the Tema-Bamako route, with about USD 4.070 Billion then the Lomé-Bamako route with USD 4.503 Billion. The Benin and Nigeria corridors offer the highest transport costs USD 5.179 Billion and USD 5.740 Billion, respectively (see Figure 6). 
Table 9. Unimodal vs. intermodal transport forecasted cost by corridor route for year 2023 (value in Million USD).

\begin{tabular}{|c|c|c|c|c|c|c|c|c|c|c|}
\hline HLLC & Corridors & $\begin{array}{c}\text { Distance } \\
(\mathrm{km})\end{array}$ & $\begin{array}{c}\text { Distance } \\
\text { Lome- } \\
\text { Mango }\end{array}$ & $\begin{array}{l}\text { Distance } \\
\text { Mango to } \\
\text { HLLC }\end{array}$ & $\begin{array}{c}\text { Av.Tr.Cost } \\
\text { by road } \\
\text { (USD/t/k } \\
\text { m) }\end{array}$ & $\begin{array}{l}\text { Av.Tr.Cost } \\
\text { by rail } \\
\text { (USD/t/k } \\
\text { m) }\end{array}$ & $\begin{array}{l}\text { Demand } \\
\text { Imp \& Exp } \\
\text { HLLC }\end{array}$ & $\begin{array}{c}\text { Unimodal- } \\
\text { Transport } \\
\text { Cost (HLLC } \\
\text { total demand) }\end{array}$ & $\begin{array}{c}\text { Intermodal- } \\
\text { Transport } \\
\text { Cost (HLLC } \\
\text { total demand) }\end{array}$ & $\begin{array}{c}\text { Transport } \\
\text { Cost } \\
\text { Saving }\end{array}$ \\
\hline \multirow{5}{*}{ Mali } & Abidjan-Bamako & 1382 & - & - & 0.17 & - & $14,780,037$ & 3472 & - & 0 \\
\hline & Cotonou-Bamako & 1947 & - & - & 0.18 & - & $14,780,037$ & 5180 & - & 0 \\
\hline & Lagos-Bamako & 1942 & - & - & 0.2 & - & $14,780,037$ & 5741 & - & 0 \\
\hline & Lome-Bamako & 1973 & 550 & 1423 & 0.16 & 0.14 & $14,780,037$ & 4666 & 4503 & 162.58 \\
\hline & Tema-Bamako & 1967 & - & - & 0.14 & - & $14,780,037$ & 4070 & - & 0 \\
\hline \multirow{5}{*}{ Niger } & Abidjan-Niamey & 1694 & - & - & 0.17 & - & $11,952,013$ & 3442 & - & 0 \\
\hline & Cotonou-Niamey ${ }^{*}$ & 1070 & - & - & 0.18 & - & $11,952,013$ & 2302 & - & 0 \\
\hline & Lagos-Niamey ${ }^{*}$ & 1028 & - & - & 0.2 & - & $11,952,013$ & 2457 & - & 0 \\
\hline & Lome-Niamey & 1222 & 550 & 672 & 0.16 & 0.14 & $11,952,013$ & 2337 & 2205 & 131.47 \\
\hline & Tema-Niamey & 1576 & - & - & 0.14 & - & $11,952,013$ & 2637 & - & 0 \\
\hline \multirow{5}{*}{$\begin{array}{c}\text { Burkina } \\
\text { Faso }\end{array}$} & Abidjan-Ouagadougou* & 1232 & - & - & - & 0.14 & $14,491,042$ & 2499 & - & 0 \\
\hline & Cotonou-Ouagadougou & 1200 & - & - & 0.18 & - & $14,491,042$ & 3130 & - & 0 \\
\hline & Lagos-Ouagadougou & 1095 & - & - & 0.2 & - & $14,491,042$ & 3174 & - & 0 \\
\hline & Lome-Ouagadougou* & 928 & 550 & 378 & 0.16 & 0.14 & $14,491,042$ & 2152 & 1992 & 159.40 \\
\hline & Tema-Ouagadougou* & 1057 & - & - & 0.14 & - & $14,491,042$ & 2144 & - & 0 \\
\hline
\end{tabular}

Source: Processed by the Author.

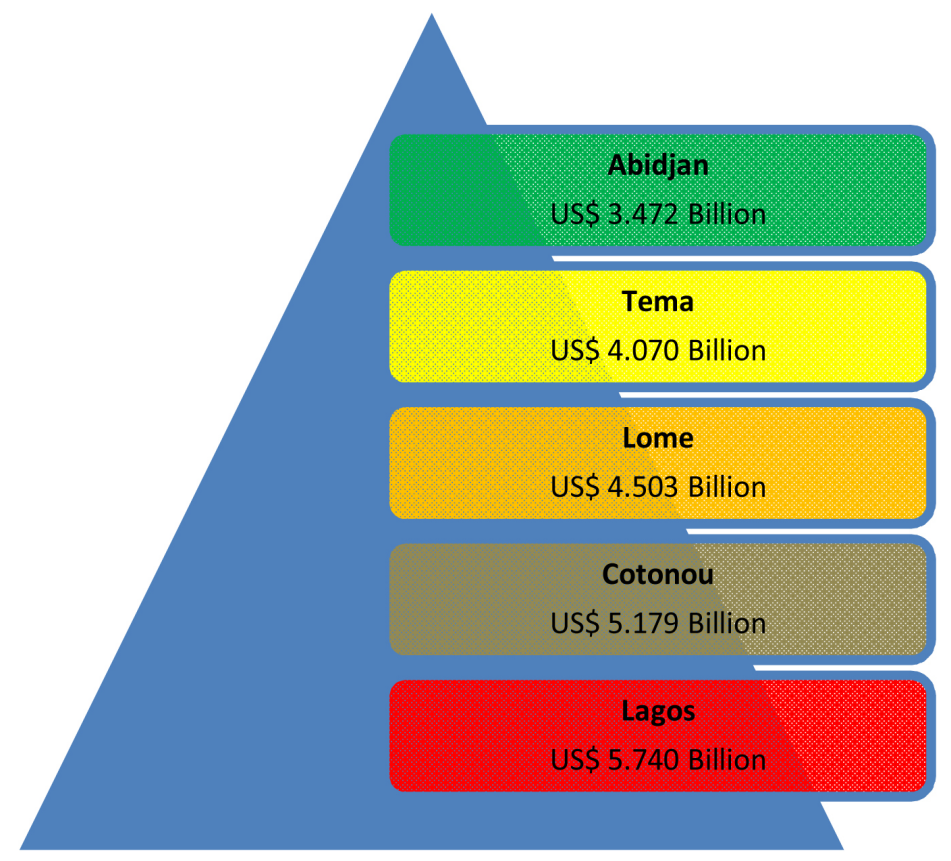

Figure 6. Forecasted unimodal vs. intermodal corridor route ranking to Bamako in MALI by year 2023. Source: Processed by the Author. 
The Togo corridor route is considered to offer the least transport cost with USD 2.205 Billion for cargo in direction to and from Niamey in Niger. The Benin and Nigeria corridors come as second and third with USD 2.301 Billion and USD 2.457 Billion respectively. Abidjan-Niamey route exhibits the highest transport cost, therefore, cannot be considered unfortunately as profitable for Niger shippers (see Figure 7).

In regard to the transit cargo to and from Ouagadougou in Burkina Faso, Togo corridor route offers the best transport cost in terms of cost minimization with USD 1.992 Billion, directly followed by Ghana corridor exhibiting a transport cost of USD 2.144 Billion and the Ivory Coast with USD 2.499 Billion. The Lagos-Ouagadougou routing holds the highest transport cost among all the routes, with the Cotonou-Ouagadougou routing closely behind (see Figure 8).

The city of Mango intermodal terminal and the application of the intermodal transport for transit cargo to and from the 3 LLCs through the Togo corridor, would enable substantial transport cost savings for shippers. This will, therefore, reflect on the final product price in the retail stores.

A shift from unimodal transport to the intermodal transport would by 2023 lead to a transport cost saving USD 162.58 Million on the Lomé-Bamako routing. The Lomé-Niamey routing transport cost saving would account for USD 131.47 Million while costing savings the Lomé-Ouagadougou routing USD 159.4 Million. An overall transport costs savings of USD 453.45 Million for the 3 LLCs understudy in the account of the year 2023 (see Figure 9).

As a result, the costs advantage to serve medium and long distance with rail is significant and is directly reflected in the pricing of intermodal transport. The

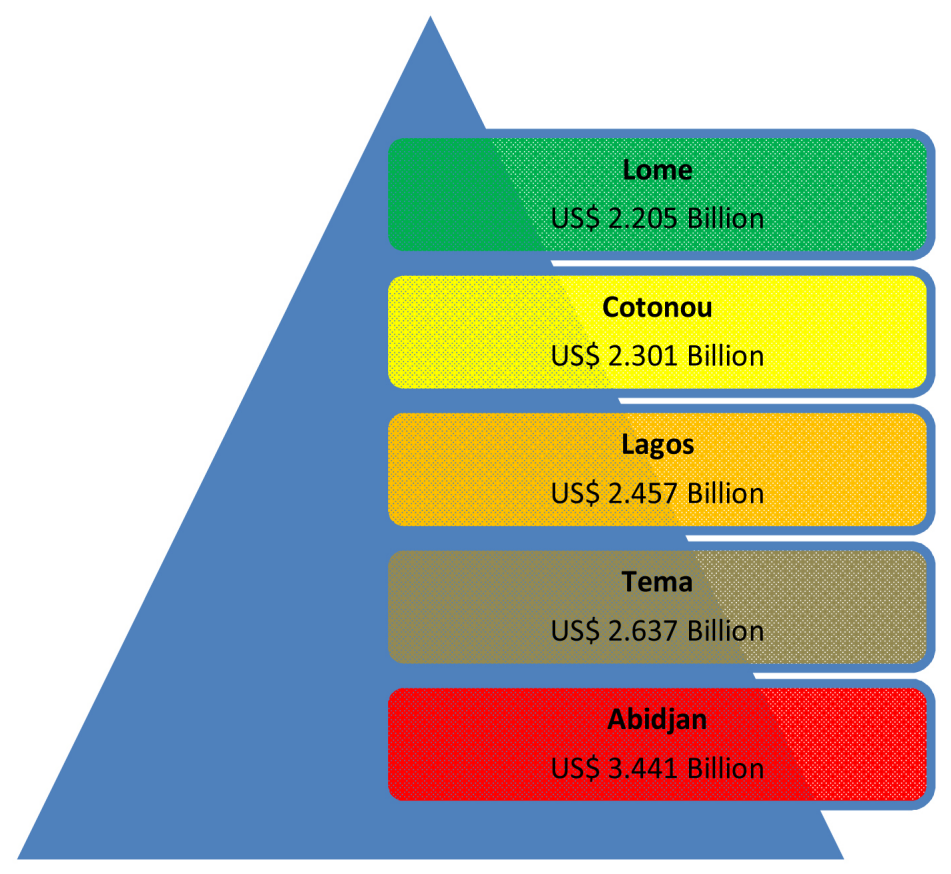

Figure 7. Forecasted unimodal vs intermodal corridor route ranking to Niamey in NIGER by year 2023. Source: Processed by the author. 


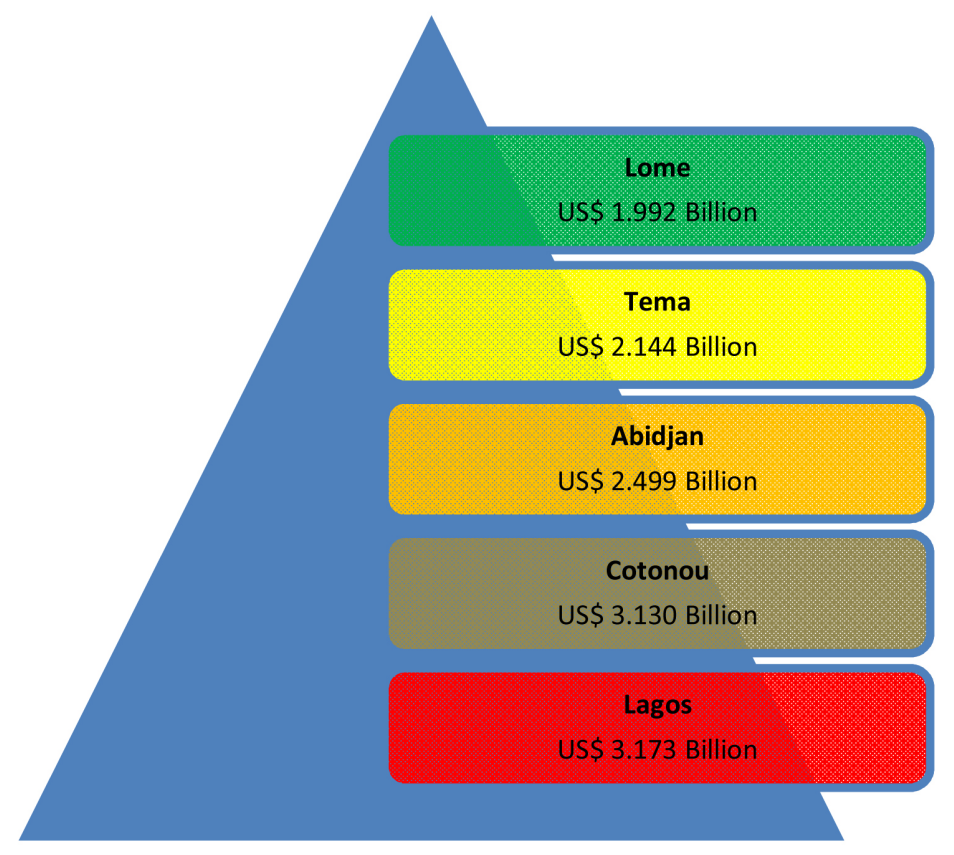

Figure 8. Forecasted unimodal vs. intermodal corridor route ranking to Ouagadougou in Burkina Faso by year 2023. Source: Processed by the Author.

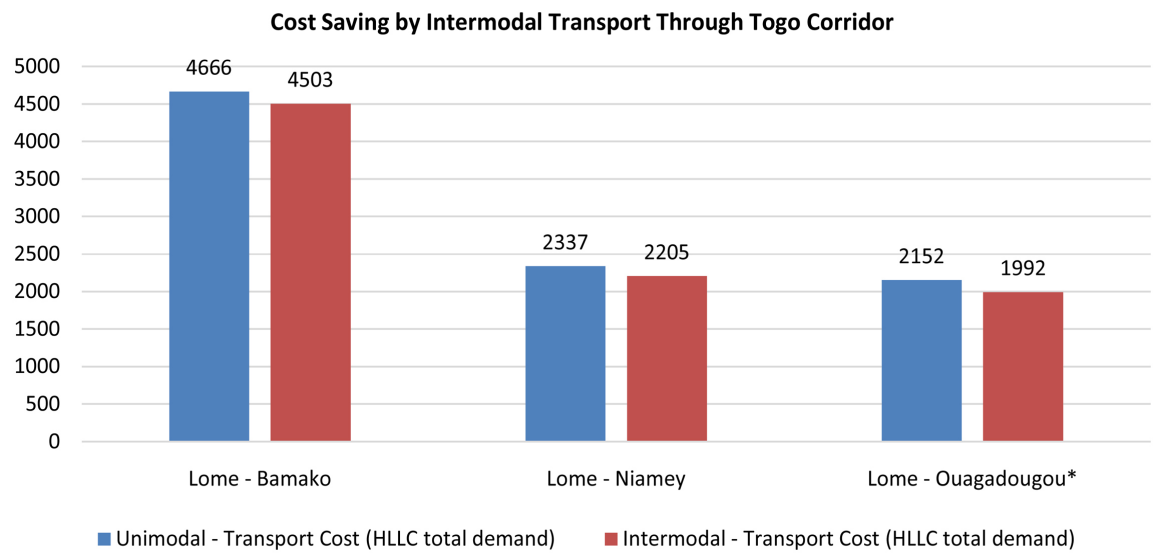

Figure 9. Forecasted cost saving by intermodal transport through Togo corridor route by year 2023. Source: processed by the Author.

rail-truck intermodal service can be a key strategy adopted to shift the high traffic density from the road to the railway. It will include the advantages of both the truck and the rail service. Pricing and willingness to pay are fundamental in the strategic planning for the development of the new infrastructure for an intermodal transport system.

The present research assumes that road distances will not alter within the time period forecasted. An average transport cost per ton-kilometer remains the same. It also assumes that transport costs are the main factors intervening in the transport decision, as we can realistically suppose that operators try to optimize the transport mechanisms. Other factors which have not been taken into account 
in this model, although they should not be neglected in the final decision, include speed, security of transport, deterioration of the goods and queuing time. The study found that the function of transport costs is most important in the transport intermodal problem, and determine the choice of cargo routing by shippers.

\section{Conclusions}

The corridor agenda is increasingly widely adopted by governments, the private sector, and development agencies. There is a realization that a poor corridor performance can hurt the economic prospects, of especially developing landlocked economies, with disproportionate impacts on their small and medium-sized enterprises (Kunaka C., \& Robin C., 2014) [45]. Trade flow in this part of Africa is unique in that they are carried on a network of five corridors, linking ports in five coastal countries (Ivory Coast, Ghana, Togo, Benin, and Nigeria) to the landlocked countries of Mali, Burkina Faso, and Niger.

In the present condition of unimodal transport, the study found that it will be more costly to ship cargo to and from Bamako through the Nigeria, Benin, Togo, and Ghana corridors. The Abidjan-Bamako routing, appears to be the most cost efficient for Mali shippers. Furthermore, still in the account of the unimodal transport, it is more costly, for shippers from Niger, to ship through the corridors of Ivory Coast, Ghana, Togo, and Nigeria. The Cotonou-Niamey cargo routing remains the most advantageous in terms of cost saving. The study also found that the Lomé-Ouagadougou cargo routing, costs more despite being the shortest distance among the studied corridors. The routes of Lagos-Ouagadougou, Cotonou-Ouagadougou, and Abidjan-Ouagadougou are not profitable to Burkinabe shippers. The Tema-Ouagadougou routing holds the first position in terms of transport costs saving, among all the corridors. Thus the study highlights that by the year 2023, Burkina Faso shippers would rather choose the Ghana corridor, while the Mali shippers would choose the Ivory Coast corridor. Shippers from Niger would go through the Benin corridor. This analysis accounted for unimodal transport, which is largely used by developing countries.

Nevertheless, the present study encourages policymakers to take into account, the recommendations of this research on the necessity of the introduction of an intermodal transport on the Togo corridor by 2023, thus meeting the Togolese PND which is a national development plan, aiming at the structural transformation of the Togolese economy. The qualitative survey conducted by this study revealed that the city of Mango would be the ideal city host for an intermodal terminal. The introduction of this parameter would change the routing habit of the shippers from the 3 LLCs. Among all the corridor under study, the Togo corridor will be considered the optimal in terms of transport cost minimization by the Niger and Burkina Faso shippers. It will face fierce competition from the Benin and Ghana corridors. The present study found that the 3 LLCs of Burkina Faso, Mali and Niger will by 2023, with the availability of the intermodal trans- 
port on the Togo corridor, enjoy a total transport cost reduction of approximatively USD 453.45 Million. Respectively, USD 162.58 Million on the Lomé-Bamako route, USD 159.4 Million on the Lomé-Ouagadougou route, and USD 131.47 Million for the Lomé-Niamey route will be saved in transport costs contrary to the unimodal transport.

\section{Conflicts of Interest}

The authors declare no conflicts of interest regarding the publication of this paper.

\section{References}

[1] Arvis, J-.F., Gaël, R. and Jean-François, M. (2010) The Cost of Being Landlocked: Logistics Costs and Supply Chain Reliability. World Bank, Washington DC. https://doi.org/10.1596/978-0-8213-8408-4

[2] Nathan Associates (2013) Logistics Cost Study of Transport Corridors in Central and West Africa. Final Report, Central \& West Africa.

[3] DANIDA (2015) Accelerating Trade in West Africa (ATWA). SAANA Consulting, Pg 26.

[4] Wang, G., Zeng, Q.C., Li, K. and Yang, J.L. (2016) Port Connectivity in a Logistic Network: The Case of Bohai Bay, China. Transportation Research Part E: Logistics and Transportation Review, 95, 341-354.

[5] Andrius, J. and Aidas, V.V. (2007) Research on Dry Port Concept as Intermodal Node. Transport, 22, 207-213.

[6] Lättiläl, L., Henttu, V. and Hilmola, O.P. (2013) Hinterland Operations of Sea Ports Do Matter: Dry Port Usage Effects on Transportation Costs and $\mathrm{CO}_{2}$ Emissions. Transportation Research Part E: Logistics and Transportation Review, 55, $23-42$. https://doi.org/10.1016/j.tre.2013.03.007

[7] Limão, N. and Venables, A.J. (2001) Infrastructure, Geographical Disadvantage, Transport Costs and Trade. The World Bank Economic Review, 15, 451-479. https://doi.org/10.1093/wber/15.3.451

[8] Arnold, J. (2005) Best Practices in Corridor Management. World Bank, Washington, DC.

http://documents.worldbank.org/curated/en/591711468314986040/pdf/451280WP0 Box3310management01PUBLIC1.pdf

[9] Degbe, S.A. (2017) An Empirical Study on Transit Traffic via West African Corridors: Case Study of Lomé-Ouagadougou. Master Thesis Dissertation, Shanghai Maritime University, Shanghai.

[10] Notteboom, T.E. and De Langen, P.W. (2016) Container Port Competition in Europe. In: Lee, C.-Y. and Meng, Q., Eds., Handbook of Ocean Container Transport Logistics-Making Global Supply Chain Effective, Springer, Cham, 75-95. https://doi.org/10.1007/978-3-319-11891-8_3

[11] Tom, V. and Cathy, M. (2016) Intermodal Land Transportation Systems and Port Choice, an Analysis of Stated Choices among Shippers in the Rhine-Scheldt Delta. Maritime Policy \& Management, 43, 992-1004. https://doi.org/10.1080/03088839.2016.1172277

[12] Michele, A., Andrea, B., Maria, I.C., Claudio, F. and Alessio, T. (2017) Contested Port Hinterlands: An Empirical Survey on Adriatic Seaports. Case Studies on 
Transport Policy, 5, 342-350. https://doi.org/10.1016/j.cstp.2017.03.006

[13] De Langen, P.W. (2007) Port Competition and Selection in Contestable Hinterlands: The Case of Austria. European Journal Transport Infrastructure Research, 7, $1-14$.

[14] Feo-Valero, M., Garcia-Menendez, L., Saez-Carramolino, L. and Furio-Prunonosa, S. (2011) The Importance of the Inland Leg of Containerised Maritime Shipments: An Analysis of Modal Choice Determinants in Spain. Transportation Research Particle E: Logistics and Transportation Review, 47, 446-460. https://doi.org/10.1016/j.tre.2010.11.011

[15] Francesetti, D.C. (2005) Italian versus Northern Range Port Competitiveness: A Transportation Cost Analysis in Chinese Trade. European Transport/Trasporti Europei, 30, 37-53.

[16] Malchow, M. and Kanafani, A. (2001) A Disaggregate Analysis of Factors Influencing Port Selection. Maritime Policy and Management, 28, 265-277. https://doi.org/10.1080/03088830110060840

[17] Malchow, M. and Kanafani, A. (2004) A Disaggregate Analysis of Port Selection. Transport Research Particle E: Logistics and Transportation Review, 40, 317-337. https://doi.org/10.1016/j.tre.2003.05.001

[18] McGinnis, M.A. (1979) Shipper Attitudes toward Freight Transportation Choice: A Factor Analytic Study. International Journal of Physical Distribution and Materials Management, 10, 25-34. https://doi.org/10.1108/eb014464

[19] Cullinane, K. and Toy, N. (2000) Identifying Influential Attributes in Freight Route/Mode Choice Decisions: A Content Analysis. Transportation Research Part E: Logistics and Transportation Review, 36, 41-53. https://doi.org/10.1016/s1366-5545(99)00016-2

[20] Tsamboulas, D.A. and Kapros, S. (2000) Decision-Making Process in Intermodal Transportation. Transportation Research Record, 1707, 86-93. https://doi.org/10.3141/1707-11

[21] Hummels, D., Carruthers, R. and Bajpai, J. (1999) Trade and Logistics: An East Asian Perspective in East Asia Integrates: A Trade Policy Agenda for Shared Growth. World Bank, 2005. https://doi.org/10.1596/0-8213-5514-7

[22] Padeco Consultants (2004) South Asia Subregional Economic Cooperation (SASEC): Subregional Corridor Operational Efficiency Study. Draft Final Report, Volume III, 07, TA No 6112.

[23] Rizk, N., Martel, A. and D’amours, S. (2006) Multi-Item Dynamic Production-Distribution Planning in Process Industries with Divergent Finishing Stages. Computers and Operations Research, 33, 3600-3623. https://doi.org/10.1016/j.cor.2005.02.047

[24] Selim, H., Am, C. and Ozkarahan, I. (2008) Collaborative Production-Distribution Planning in Supply Chain: A Fuzzy Goal Programming Approach. Transportation Research Part E: Logistics and Transportation Review, 44, 396-419. https://doi.org/10.1016/j.tre.2006.11.001

[25] Lee, Y.H. and Kim, S.H. (2000) Optimal Production-Distribution Planning in Supply Chain Management Using a Hybrid Simulation-Analytic Approach. Proceedings of the 2000 Winter Simulation Conference, Orlando, FL, 10-13 December 2000, 1252-1259. https://doi.org/10.1109/wsc.2000.899093

[26] Chern, C.C. and Hsieh, J.S. (2007) A Heuristic Algorithm for Master Planning that Satisfies Multiple Objectives. Computers and Operations Research, 34, 3491-3513. https://doi.org/10.1016/j.cor.2006.02.022 
[27] Jang, Y.J., Jang, S.Y., Chang, B.M. and Park, J. (2002) A Combined Model of Network Design and Production/Distribution Planning for a Supply Network. Computers and Industrial Engineering, 43, 263-281. https://doi.org/10.1016/s0360-8352(02)00074-8

[28] Cathy, M., An, C., Bart, J. and Ethem, P. (2011) A Decision Support Framework for Intermodal Transport Policy. European Transport Research Review, 3, 167-178. https://doi.org/10.1007/s12544-011-0062-5

[29] Barnhart, C. and Ratliff, H.D. (1993) Modeling Intermodal Routing. Journal of Business Logistics, 14, 205-223.

[30] Boardman, B.S., Malstrom, E.M., Butler, D.P. and Cole, M.H. (1997) Computer Assisted Routing of Intermodal Shipments. Computers and Industrial Engineering, 33, 311-314. https://doi.org/10.1016/s0360-8352(97)00100-9

[31] Jencek, P. and Twrdy, E. (2008) Development of Regional Transport Logistics Terminal. Transport Logistics Approach, 20, 239-249.

[32] Cathy, M. (2001) The Optimal Location of an Intermodal Terminal: A Real World Application. Nectar Conference No. 6, European Strategies in the Globalising Markets, Transport Innovations, Competitiveness and Sustainability in the Information Age, Helsinki.

[33] Harper, D.V. and Evers, P.T. (1993) Competitive Issues in Intermodal Railroad-Truck Service. Transportation Journal, 32, 31-45.

[34] Portugal, L.D.S., Morgado, A.V. and Lima, O.J.R. (2011) Location of Cargo Terminals in Metropolitan Areas of Developing Countries: The Brazilian Case. Journal of Transport Geography, 19, 90-100. https://doi.org/10.1016/j.jtrangeo.2010.11.005

[35] Rickard, B. and Jonas, T. (2008) Evaluating Locations for Intermodal Transport Terminals. Transportation Planning and Technology, 31, 465-485. https://doi.org/10.1080/03081060802335125

[36] Macharis, C. and Verbeke, A. (1999) Een Multicriteria-Analyse Methode voor de Evaluatie van Intermodale Terminals. Tijdschrift Vervoerswetenschap, 4, 323-352.

[37] Sirikijpanichkul, A., van Dam, K. H., Ferreira, L. and Lukszo, Z. (2007) Optimizing the Location of Intermodal Freight Hubs: An Overview of Agent Based Modelling Approach. Journal of Transportation Systems Engineering and Information Technology, 7, 71-81. https://doi.org/10.1016/s1570-6672(07)60031-2

[38] Sirikijpanichkul, A. and Ferreira, L. (2005) Multi-Objective Evaluation of Intermodal Freight Terminal Location Decisions. The 27 th Conference of Australian Institute of Transport Research (CAITR), Queensland University of Technology, Brisbane, 7-9 December 2005, 1-16.

[39] PMAWCA (2016). http://www.agpaoc-pmawca.org

[40] Google Map (2019). https://www.google.com/maps/

[41] Blonigen, B. and Wilson, W. (2006) International Trade, Transportation Networks and Port Choice. Manuscript, University of Oregon, Eugene, OR.

[42] Executive Secretariat, Borderless Alliance (2016) Regional Integration through the Development of Trade and Transport.

[43] Descombe (1998) Introduction to Questionnaire Design. University of Glasgow, Glasgow. http://www.gla.ac.uk/t4/education/files/scre/question.pdf

[44] Rajiv, D., Rabindra, N.B., Behzad, G. and Aditya, P. (2011) Optimal Pricing and Terminal Location for a Rail-Truck Intermodal Service-A Case Study. Interna- 
tional Journal of Logistics Research and Applications, 14, 335-349. https://doi.org/10.1080/13675567.2011.643778

[45] Kunaka, C. and Robin, C. (2014) Trade and Transport Corridor Management Toolkit. World Bank, Washington DC. 


\title{
Appendices
}

\section{Appendix 1: Invitation to Participate Letter-Survey}

\section{TO WHOM IT MAY CONCERN}

\section{Dear Sir/Madam,}

You are invited to complete an academic research survey. If you would like to participate in the evaluation, you will be asked to complete this survey. This research seeks to investigate the present transport mode of transit containers from the Port of Lomé to the land-locked countries, as well as exploring the possible transport mode optimization of the transit traffic of containers cargo. It will take about 30 minutes to finish. Your participation is completely voluntary and very much solicited. This survey is purely in the context of academic research.

There is no cost for you to participate in the evaluation and you receive no compensation in exchange for your participation in this survey. Your inputs are extremely valuable to this research for your opinion on the appropriate mode of transport in terms of efficacy and efficiency along the corridor of Lomé-Cinkassé. I will be very grateful if you could help out in answering this academic survey.

I solely assure you that all answers and information obtained from this academic survey remain totally confidential and will be generally analysed with specific reference to you or your organization and be used for academic purposes only.

Each respondent will be handed one (1) copy of this survey and kindly tick $[\sqrt{ }]$ the box below or fill the blank space where applicable.

Looking forward to your contribution.

\author{
Sincerely, \\ Bomboma Kalgora \\ PhD. Candidate \\ School of Economics and Management \\ Shanghai Maritime University \\ Shanghai, China \\ Email: research.kb@outlook.com
}




\section{Appendix 2}

Answer the following prompts to develop a participant-specific ID number. Note that each participant should be assigned his/her own specific ID number because this ID will be used to link a participant's pre-survey and post-survey.

1- The first 2 letters of participant's First Name

2- The first 2 letters of participant's Last Name

3- Date participant was born (2 digits)

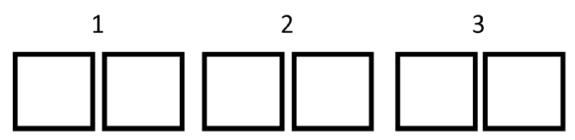

EXAMPLE:
Developing an ID Number
for Jane Doe
Name: Jane Doe
Date of Birth: 04/21/90
ID\#: JADO21

SQ1. What is your function along the Lomé-Cinkassé transit corridor?

Freight Forwarder

Container Truck Operator

Transit Importer

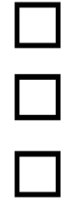

Other:

SQ2. To reduce transit time and cost, to enhance efficiency and reliability of container transport goods along the Lomé-Cinkassé corridor, do you think the introduction of an intermodal transport mode would be profitable for the actors of the transport sector?

Yes

No

SQ3. In response to $\mathrm{SQ} 2$, Why?

SQ4. Based on your answer, what town along the corridor you suggest as an intermodal terminal (i.e. Hub)?

Blitta (263km from Lomé)
Kara (411 km from Lomé)
Mango (550 km from Lomé)
Dapaong (620 km from Lomé)

Other(s):

SQ5. Your remarks or suggestions for optimization of transport capacities to policymakers?

Note: Please if you wish to receive the general results of this academic survey or have any queries, kindly contact me through email.

THANK YOU FOR YOUR KIND ASSISTANCE AND PRECIOUS TIME 